\title{
Perbandingan Standar Sarana Dan Prasarana SMP Swasta Dan SMP Negeri
}

\author{
Elyakim Nova Supriyedi Patty ${ }^{1}$, Cornelia Sri Sulasmi Padak ${ }^{2}$, Anjelina Gheda Bara ${ }^{3}$, \\ Frenly Marta Ate ${ }^{4}$, Febiola Kartika Wurung ${ }^{5}$, Elisabet Kaley ${ }^{6}$, Klemensia Maria Renda ${ }^{7}$ \\ ${ }^{1-7}$ Program Studi Pendidikan Fisika STKIP Weetebula
}

*Corresponding Author: Elyakim N. S. Patty, STKIP Weetebula;

Email:

elyakim_nsp@yahoo.co.id

\begin{abstract}
Manajemen sekolah merupakan sebuah prosedur untuk menertibkan sekolah agar proses pembelajaran dapat berjalan dengan lancar. Dalam dunia pendidikan tidak terlepas dari Manajemen Sekolah dimana di dalamnya terdapat beberapa bagian yang memfasilitasi berjalannya proses pembelajaran. Berdasarkan kondisi ini, kami melakukan perbandingan pelaksanaan manajemen sekolah di dua sekolah yang berada di Sumba Barat Daya yaitu SMP Seminari Sinar Buana dan SMPN 1 Loura dengan tujuan untuk mengetahui pengelolaan manajemen sarana dan prasarana yang tersedia di kedua sekolah tersebut. Berdasarkan hasil wawancara kami memperoleh informasi bahwa kedua sekolah tersebut memiliki perbandingan sarana dan prasarana yang cukup baik. Dimana diperoleh hasil sebagai berikut: kedua sekolah tersebut merupakan dua dari sekolah favorit jenjang SMP dalam kategori sekolah swasta dan sekolah negeri yang ada di SBD. SMP Negeri 1 Loura memiliki jumlah siswa yang sangat banyak. Namun, disisi lain SMP Seminari Sinar Buana memiliki jumlah siswa yang sedikit lantaran sekolah ini merupakan sekolah khusus calon imam. SMP Seminari Sinar Buana memiliki suatu keunggulan dimana mata pelajaran yang terdapat pada sekolah tersebut berbeda dengan sekolah lain seperti SMP Negeri 1 Loura, karena merupakan sekolah khusus sekolah ini menambahkan mata pelajaran Bahasa Latin, Liturgi, Ekaristi dan juga memiliki sarana laboratorium MIPA, laboratorium Bahasa dan Laboratorium komputer yang memadai berjalannya proses pendidikan di sekolah ini. Disisi lain SMP Negeri 1 Loura memiliki jumlah siswa yang banyak, namun fasilitas ruang kelas, ruang lab dan mebeler yang ada pada SMP Negeri 1 Loura tersebut masih sangat kurang dan perlu ditambahkan, serta belum memiliki laboratorium bahasa. Dengan kondisi ini, nampak bahwa walaupun berstatus sekolah negeri pada kenyataannya sekolah ini masih kurang lengkap fasilitasnya ketimbang sekolah swasta. Untuk itu menurut pandangan peneliti, sekolah ini haruslah membenahi sistem manajemen yang berlangsung di sekolah terseut agar tidak kalah unggul dari sekolah lainnya. Sebab, dengan manajemen yang baik sebuah sekolah akan lebih terjamin dalam hal pelaksanaan proses pendidikan dan mutu pendidikannya
\end{abstract}

Keywords: Standar Sarana dan Prasarana

\section{Pendahuluan}

Dalam era globalisasi saat ini, dunia pendidikan merupakan salah satu landasan yang sangat penting dimiliki oleh suatu daerah guna mendukung proses berkembangnya pengetahuan dan pemahaman yang utuh terkait berbagai macam fenomena kehidupan yang mungkin saja dapat terjadi. Namun, dalam hal ini aspek pendidikan akan berjalan dengan baik manakala ada tempat bernaung yang senantiasa mampu mewujudkan kemajuan yang didambakan. Oleh kerena itu, sekolah-sekolah yang ada di suatu daerah dapat menjadi jawaban untuk mencapai apa 
yang telah direncanakan untuk kemajuan suatu bangsa.

Dalam hal memajukan bangsa pun, kita memerlukan banyak hal yang nantinya saling berkaitan satu sama lain. Oleh karena itulah sebuah sekolah yang baik harus mampu memanajemen sekolahnya dengan tepat. Sebab pendidikan yang berkualitas terdapat pada sekolah yang berkualitas dan salah satu ciri sekolah yang bergerak maupun yang tidak bergerak untuk mencapai tujuan pendidikan dengan lancar, teratur, efektif dan efisien (Suryosubroto, 2009). Manajemen sekolah yang baik, salah satunya dapat nampak pada bidang sarana dan prasarana. Seperti menurut pendapat Fauzan (2016) prasarana adalah fasilitas yang secara tidak langsung menunjang proses pembelajaran yang berlangsung disekolah, yang meliputi bangunan sekolah, lapangan olahraga, dan halaman sekolah. Dalam hal ini, prasarana yang digunakan dalam proses pembelajaran yang produktif adalah ketersediaan bangunan sekolah, lapangan olah raga, dan halaman sekolah. Bangunan sekolah adalah gedung yang dipergunakan untuk proses pembelajaran dalam kelas maupun ruang yang digunakan untuk melakukan praktikum. Sehingga sebuah sekolah harus melakukan standar pengelolaan sesuai dengan Peraturan Pemerintah Nomor 32 Tahun 2013 tentang standar Nasional Pendidikan yang menjelaskan bahwa standar pengelolaan itu terdiri dari tiga bagian yaitu standar pengelolaan oleh satuan pendidikan, standar pengelolaan oleh pemerintah daerah, dan standar pengelolaan oleh pemerintah pusat.

Kehadiran sarana dan prasarana di sekolah-sekolah memerlukan pengelolaan yang baik secara bertahap dan berkelanjutan sehingga sekolah dapat memenuhi kriteria atau standar yang telah ditetapkan oleh pemerintah, sebab proses pembelajaran akanberhasil dipengaruhi oleh keberfungsian sarana dan prasarana yang ada di suatu sekolah. Dan satu hal yang tidak dapat dihindarkan yaitu, berhasilnya suatu sarana prasarana juga turut dipengaruhi oleh kualitas sumber daya manusia yang berada dalam lembaga sekolah. Sumber daya manusia yang dimaksudkan adalah segala komponen pendidikan seperti komite sekolah, kepala sekolah, guru, staff, maupun siswasiswinya. Sebagai salah satu sumber daya manusia, kehadiran guru pada suatu lembaga pendidikan harus sesuai atau harus mampu mengkover jumlah siswa yang dimiliki oleh sekolah tersebut, atau jumlah guru haruslah seimbang dengan banyaknya siswa di suatu sekolah. Sehingga ada keteraturan, kualitas pengajaran dan kenyamanan dalam belajar yang dapatdialami oleh setiap rombongan belajar di sekolah.Jika sumber daya manusia yang dimiliki oleh suatu sekolah tidak berkompeten, maka dapat dpastikan pendidikan yang berjalan di sekolah tersebut mengalami kendala atau tersendat-sendat dalam proses perjalannannya mencapai tujuan pendidikan yaitu mencerdaskan kehidupan bangsa. Maka dalam hal ini, antara sumber daya manusia dan sarana prasarana yang ada haruslah seimbang, setiap bagian memahami fungsinya dan memahami bagaimana mengelola sarana dan prasarana yang ada meliputi kegiatan perencanaan, pengadaan, inventaris, dan pemanfaatan sarana dan prasarana yang ada. Oleh karena itu penulis akan menyajikan hasil pengkajian pengelolaan sarana dan prasarana oleh dua lembaga pendidikan yang sudah lama berkiprah di tanah marapu (Sumba Barat Daya).

\section{Metode}

Metode penelitian yang dilakukan oleh penulis adalah metode kualitatatif deskriptif(Sugiono:24) dengan menggunakan pendekatan wawancara dan portofolio ke sekolah-sekolah yang menjadi tujuan pengambilan data. Salah satu tujuan dari penelitian ini adalah untuk mengetahui bagaimana perkembangan dunia pendidikan yang telah dicapai oleh dua sekolah yang ada di Sumba Barat Daya yaitu SMP Seminari Sinar Buana dan SMP Negeri 1 Loura. Selain itu juga dari penelitian ini akan nampak kesamaan dan perbedaan antara sekolah swasta dan negeri dalam melakukan manajemen pendidikan di sekolahnya. Selain wawancara dan observasi langsung penulis juga melakukan pengambilan dokumentasi.

\section{Hasil dan Pembahasan}

\section{Hasil}

SMP Seminari Sinar Buana, merupakan salah satu sekolah yang kehadirannya di tanah Sumba sebagai sekolah khusus setiap anak laki-laki yang ingin menjadi imam untuk langkah pengabdian dalam hidupnya. Sekolah ini telah berdiri sejak 1 Juli 1994. Di sekolah khusus yang juga tergolong kedalam sekolah swasta, penulis menemukan bahwa sekolah ini pada saat dilakukan observasi sudah memiliki sarana dan prasarana yang baik dalam menunjang proses kegiatan belajar mengajar. Sekolah ini 
memiliki 3 gedung yang dipergunakan untuk ruang kelas atau ruang belajar siswa sebanyak 111 orang dan terdiri atas 9 ruangan kelas, 1 laboratorium IPA, 1 laboratorium komputer, 1 laboratorium bahasa, 1 ruang guru dan staff, 1 ruang kepala sekolah, 1 ruang tata usaha, 1 ruang UKS, 1 ruang perpustakaan, lahan parkir, asrama siswadan fasilitas-fasilitas yang membantu peserta didik dalam mengembangkan minat dan bakatnya masing-masing, seperti olahraga, menyanyi dan menari sudah disediakan alatnya masing-masing.

SMP Negeri 1 Loura merupakan sekolah negeri yang terletak di kabupaten Sumba Barat Daya kecamatan Kota Tambolaka. Untuk sarana dan prasarana, sekolah ini memiliki jumlah ruang kelas sebanyak 21 ruangan yang dapat menunjang pembelajaran siswa yang berjumlah 829 orang. Selain ruang kelas, sekolah ini juga memiliki 1 ruang Aula, 1 perpustakaan, 1 ruang laboratorium komputer, 1 kantin sekolah, dan lahan parkir.

\section{Pembahasan}

SMP Seminari Sinar Buana merupakan salah satu sekolah Favorite di Sumba Barat Daya dimana sekolah ini sudah memiliki fasilitas yang memadai.Meskipun sekolah ini tergolong sekolah favorite peserta didik terbanyak barasal dari luar Sumba seperti Flores sementara peserta didik dari Sumba itu sendiri masih sangat minim. Seiring berjalannya waktu, masyarakat di Pulau Sumba pada khususnya SumbaBarat Daya (SBD) mulai menyadari bahwa sekolah ini sangat bermutu dan ouput yang dihasilkan sangat berkualitas sehingga peserta didik dari masyarakat Sumba sendiri mulai mengalami peningkatan untuk mengenyam Pendidikan di sekolah ini. Mengapa sekolah ini tergolong sekolah favorite? Hal ini karena sekolah ini memiliki kelebihan tersendiri dimana dalam segi mata pelajaran ada beberapa mata pelajaran yang ditambahkan seperti Bahasa Latin, liturgi, dan Ekaristi.Sedangkan dalam segi sarana dan prasarana terdapat laboratorium Bahasa yang digunakan untuk membantu menunjang kemampuan belajar peserta didik dalam proses pembelajaran. Dan beberapa poin penting adalah sekolah ini sudah terakreditasi A dan memiliki guru-guru yang berkompeten dalam bidang ilmu pengetahuannya.

SMP Negeri 1 Loura juga merupakan sekolah negeri yang sangat digemari oleh masyarakat di Sumba Barat Daya. Sekolah ini juga memiliki fasilitas yang cukup memadai danmemiliki jumlah siswa yang berjumlah 829 orang dengan jumlah guru 45 orang. SMP Negeri 1 Loura menjadi salah satu sekolah favorite karena sekolah ini merupakan salah satu sekolah Negeri yang ada di Sumba Barat Daya (SBD). SMP Negeri 1 Loura memiliki jumlah siswa yang besar meskipun dari segi sarana prasarana masih ada beberapa kekurangan yang meliputi fasilitas mebeler yeng sedikit jumlahnya seperti kursi dan meja perlu ditambahkan.

Berdasarkan hasil penelitian yang kami lakukan di SMP seminari Sinar Buana kami memperoleh data sebagai berikut:

\begin{tabular}{|l|l|l|}
\hline No & Nama fasilitas & Jumlah \\
\hline 1 & Ruang kelas & 9 \\
\hline 2 & Ruang perpustakaan & 1 \\
\hline 3 & Ruang laboratorium Bahasa & 1 \\
\hline 4 & Ruang laboratorium MIPA & 1 \\
\hline 5 & Laboratorium computer & 1 \\
\hline 6 & Ruang tata usaha & 1 \\
\hline 7 & Ruang guru & 1 \\
\hline 8 & Ruang kepala sekolah & 1 \\
\hline 9 & Kantin & 1 \\
\hline 10 & Lapangan bola volley & 1 \\
\hline 11 & Lapangan bola kaki & 1 \\
\hline 12 & Ruang aula & 1 \\
\hline 13 & Perlengkapan olah raga & Lengkap \\
\hline 14 & Perlengkapan pentas seni & Lengkap \\
\hline
\end{tabular}

Sedangkan pada SMP Negeri 1 Loura kami memperoleh data sebagai berikut:

\begin{tabular}{|l|l|l|}
\hline No & Nama fasilitas & Jumlah \\
\hline 1 & Ruang kelas & 21 \\
\hline 2 & Ruang aula & 1 \\
\hline 3 & Ruang perpustakaan & 1 \\
\hline 4 & Laboratorium komputer & 1 \\
\hline 5 & Kantin & 1 \\
\hline 6 & Lahan parkir & 1 \\
\hline 7 & Laboratorium MIPA & 1 \\
\hline
\end{tabular}

Tabel 2. Sapras SMP Negri 1 Loura

Berdasarkan data-data yang kami peroleh antara kedua sekolah tersebut maka kami melakukan perbandingan sebagai berikut: perbandingan antara kedua sekolah tersebut dapat kita lihat pada tabel diatas dimana antara kedua sekolah tersebut memiliki sarana prasarana yang cukup mengalami perbedaan, seperti pada SMP Negeri 1 Loura kurangnyalaboratorium Bahasa dan fasilitas 
mebeler yang belum memadai dengan jumlah siswa yang dimiliki oleh sekolah tersebut.

\section{Kesimpulan}

Berdasarkan hasil penelitian yang kami lakukan berkaitan dengan pengelolaan sarana dan prasarana antara kedua sekolah yakni SMP Seminari Sinar Buana dan SMP N 1 Loura maka dapat kami simpulkan sebagai berikut; sarana dan prasarana yang tersedia pada kedua sekolah tersebut cukup menunjang proses pembelajaran pada kedua sekolah tersebut. Yang walaupun SMP Seminari lebih unggul dari segi fasilitas yang tersedia. Dengan unggulnya fasilitas yang dimiliki SMP Seminari, adabaikya SMPN 1 Loura semakin meningkatkan kualitas pengelolaan manajemen di sekolahnya agar proses pembelajaran dapat berjalan dengan lebih baik, misalnya dengan melengkapi fasilitas sarana dan prasarana yang mampu memenuhi kebutuhan proses pendidikan disesuaikan dengan banyaknya jumlah siswa. Adapun sarana dan prasarana dari kedua sekolah tersebut yaitu ruang kepala sekolah, ruang guru, ruang kesiswaan, ruang staf, ruang tata usaha, ruang kelas, perpustakaan, ruang laboratorium MIPA, ruang laboratorium Bahasa, ruang laboratorium komputer, aula, kantin sekolah, dan tersedia juga ruang UKSyang digunakan untuk menyimpan obat-obatan apabilaada pesertadidik yang mengalami keadaan yang kurang baik (sakit).Dengan sarana prasarana yang ada ini maka peserta didik dapat lebih nyaman untuk belajar serta dapat menghasilkan ouput yang baik pula tentunya diimbangi dengan bimbingan para guru dan staff yang berkompeten dibidannya masing-masing.

\section{Saran}

Sebuah sekolah yang baik adalah sekolah yang memiliki jumlah sarana dan prasarana yang cukup memadai. Oleh karena itu kami menyarankan agar sekolah yang sarana prasarananya belum terpenuhi agar dipenuhi. Sehingga sekolahnya lebih nyaman untuk ditempati oleh siswa-siswa yang belajar. Salah satu caranya dengan meningkatkan manajemen sekolah yang selaras dengan tujuan pendidikan dan berpedoman pada peraturan Pemerintah tentang Standar Pendidikan Nasional. Kami mengharapkan semoga artikel ini dapat bermanfaat bagi para pembaca terutama bagi para pendidik, dan masyarakat pada umumnya.

\section{Daftar Pustaka}

Fauzan. 2016.Pengantar Sistem Administrasi-Teori dan Praktik. Yogyakarta: UII Press Yogyakarta.

Peraturan Pemerintah Nomor 32 Tahun 2013 tentang Perubahan Atas Peraturan Pemerintah Nomor 19 Tahun 2005 Tentang Standar Nasional Pendidikan.

Sugiyono. 2008. Metode Penelitian Kuantitatif, Kualitatif, dan R\&D. Bandung: Alfabeta.

Suryosubroto. 2019. Proses Belajar Mengajar Di Sekolah. Jakarta: PT. Rineka Cipta. 